European Fournal of Education, Vol. 43, No. 4, 2008

\title{
The Emergence and Institutionalisation of the European Higher Education and Research Area
}

\section{ERIC BEERKENS}

\section{Introduction}

In the 50 years of European integration, rules, regulations and policies were formulated to facilitate flows of products and people; those who benefited from the increasing transnational exchange urged European actors to remove remaining obstacles and further facilitate European trade and mobility. This dynamic is present in nearly all policy domains where there is a significant level of transnational activity. In the field of higher education and research, this transnational activity has increased in the last decades and has led - as I will argue in this article - to the emergence of European rules, a strengthening of European institutions and the development of a European higher education and research community. This article will approach Europeanisation as the emergence of a new layer of governance, a layer with a wide range of interacting actors. The question addressed here is: to what extent has a European higher education and research area (EHERA) emerged and through what mechanisms is it being sustained? The discussion of research in the European context will mainly be limited to those activities that show a direct link with higher education institutions, not the private R\&D sector. First, the extent to which this area has emerged will be analysed, and secondly, the mechanisms that have driven the institutionalisation of the EHERA will be studied. Before that, however, I will introduce the approaches and perspectives through which I will examine the process of institutionalisation at the European level.

\section{Transnational Activity and European Governance}

A central question in the European integration debate is whether integration is basically an inter-governmental bargaining process in which nations collectively articulate their individual national interests (Moravcsik, 1993), or whether it has developed the characteristics of a supra-national State in which a new level of governance covers the region as a whole, not as individual nation-states (Sandholtz \& Stone Sweet, 1998; building on the early neo-functionalist work of Haas, 1958; Lindberg, 1963; Nye, 1970). In the latter claim, actors and institutions operating above and across the nation-states acquire a degree of autonomy and become independent actors. Europeanisation processes in the field of higher education and research show elements of both perspectives. Due to the national sensitivity of education and some types of scientific research, countries are very hesitant to give up any sovereignty in these fields, and thus they will try to tackle issues with a 
European dimension in an inter-governmental manner, leaving European educational and research policy in the hands of the lowest common denominator in this bargaining process. At the same time, elements of supranationalism can be identified: education and research have been incorporated in the treaties and have become linked to other provisions in the treaties; directorates for these sectors have been established and their programmes are being executed and funded by European institutions; and in some ways, national governments are becoming constrained by European rules and the interpretations of these rules by the European Court of Justice. A useful approach is to see the distinction between inter-governmentalism and supranationalism as a continuum between two extremes, an approach that also allows for different speeds of integration for different policy sectors or sub-sectors. A transaction-based approach to European integration allows for such an interpretation of integration (Sandholtz \& Stone Sweet, 1998).

The starting point of the approach is that the relative intensity of transnational activity causes shifts in the level of supranational governance. Different policy sectors may find themselves in different positions on the intergovernmentalsupranational continuum. The level of supranational governance can be assessed on the basis of three dimensions (Stone Sweet \& Sandholtz, 1998, p. 6): EU rules, EU organisations and transnational society. On the intergovernmentalsupranational continuum, EU rules achieve higher degrees of formalisation, EU institutions gain more autonomy and transnational actors become more present and more influent. Stone Sweet and Sandholtz (1998, p. 17) follow Haas' argument that there is a logic of institutionalisation at work in European integration:

As European rules emerge and are clarified and as European organizations become arenas for politics, what is specifically supranational shapes the context for subsequent interactions: how actors define their interests, what avenues are available to pursue them, how disputes are to be resolved. This creates the 'loop' of institutionalisation.

This logic implies that changes in any one of the three dimensions - EU rules, EU organisations and transnational society - will tend to produce change in the other two. The need or desire for more transnational activity - like trade or migration - does not emerge in order to - intentionally - bring about further supranational regulation, but will usually emerge spontaneously out of sheer curiosity, pressures for efficiency, search for profits, or through stimuli from national governments or supranational institutions. If this activity is substantial enough, it will trigger further supranational regulation in order to coordinate these transnational activities. The expansion of transnational activity thus pushes for supranational governance, which is exercised to facilitate and regulate that activity. The transnational activity will also activate the organisation and representation of transnational actors in order to promote their transnational European interests. These transnational groups push for the transfer of policy competences to supranational bodies, finding each other and establishing cross-national coalitions along the way. The members of this transnational society - the European associations and organisations in the field of higher education and research - try to influence supranational organisations but also assist them in acquiring information, expertise and legitimation and therewith reinforce their authority. As transnational society 
becomes more intense and influential, transnational exchange and communication increases and so does the demand for supranational rules and organisations' capacity to regulate. As the remaining sections of this article will demonstrate, this approach clarifies the links between supranational governance and transnational activity and also exposes the underlying mechanisms that lead to greater Europeanisation of the field of higher education and research.

\section{Transnational Activity in European Higher Education and Research}

Measuring and defining transnational activity in the European domain is easier for some policy domains than for others. Economic integration has been the prime focus of European policies and regulations and, in this respect, transnational activity can be measured relatively simply by the amount of intra-European trade (Fligstein \& Stone Sweet, 2002). For non-economic domains, the measurement of transnational activity, or what is transacted and exchanged across borders, is less straightforward. Higher education and research in Europe are predominantly activities in the public domain and do not fall within the category of commercial services. People however do cross borders in order to receive or provide these public services and they collaborate in order to produce new knowledge. Therefore, the most important and obvious indicators for transnational activity in the EHERA are the mobility of individual students and academics and the collaboration and exchange between academics.

In the case of student mobility one tends to think of programmes like Erasmus or Socrates. This type of organised mobility, however, is only a small proportion of the total mobility within Europe. The available data on unorganised mobility show a steady increase, especially in the late 1980s and early 1990s (Figure 1). Clearly, most of the intra-European mobility across borders is caused by spontaneous mobility or free movers, rather than by the mobility in the framework of the Erasmus Programme.

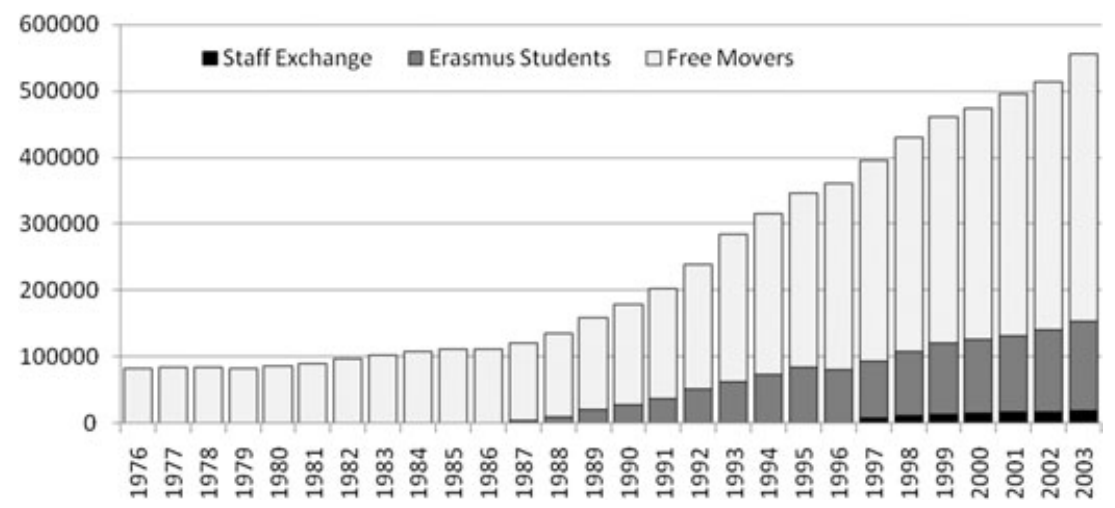

FiguRE 1. Intra-European Mobility 1976-2003 (UNESCO, 1978-1999'; European Commission, 2006)

Exchange of staff within the European programmes is low but this does not necessarily mean that the overall mobility of academic staff is low. Although 
there are no direct data, it is plausible to assume that academic staff collaborate more with foreign colleagues and visit more foreign universities than ever before. The European cooperation programmes for instance, have not only encouraged mobility, they have also stimulated cooperation. Various so-called 'Socrates Actions' were established in the past decades and all of them required some type of inter-institutional cooperation and exchange. In 2005, 90\% of Europe's universities and higher education institutions were involved in these university networks and cooperation projects (European Commission, 2005). In the Socrates framework alone, more than 860 of these cooperative actions were coordinated by higher education institutions in Europe between 1994 and 2004 (ISOC, 2007). These have resulted in joint curricula, joint conferences, research reports, publications and a wide range of other actions that promote joint knowledge creation and dissemination. In the framework of Erasmus Mundus, the Commission requires the establishment of higher education consortia in order to offer a joint Masters programme. Four years after the launch of Erasmus Mundus, 80 such consortia are active. In the field of research, the prerequisite of cooperation is also apparent. For most of the Framework Programme activities it is required for researchers to form networks with colleagues from other Member States. All these cooperative ventures require communication by phone, email and Internet, face-to-face meetings of academics and other staff and the exchange of information and ideas. But it is not just about organised cooperation in the European programmes. Higher education and research have always been characterised by international cooperation but cooperation has become easier because of open borders and new technologies. The result of the intense cooperation and exchange of ideas and information can be observed if we look at scientific publications. For all of the EU 15 countries (the pre-2004 EU), the number of co-authored publications with other countries of the EU 15 has increased steadily since the late 1980s (Figure 2).

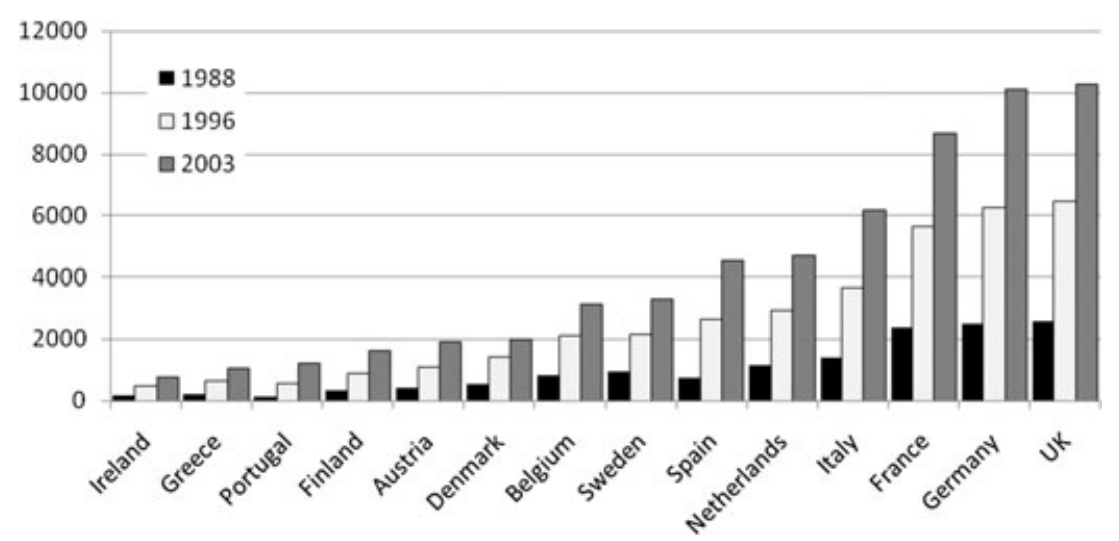

FIgURE 2. European Co-authored Articles (National Science Foundation, 2006)

This, together with the thick academic networks in the frame of official European Programmes, is a clear indication of the increased transnational activity, 
be it through the exchange of people or the exchange of intangible assets such as ideas. The theoretical approach outlined in the previous section argues that these expanding and intensifying transnational flows of people, information and ideas cause a demand for a supranational layer of governance.

\section{The Emergence of the EHERA}

\section{Education, Research and European Law}

In the Treaty of Rome, education as such was not included as a competence of the EU. It was not incorporated in the treaties of the EU until the Treaty of Maastricht in 1992. A few provisions did however show a link with higher education. The most obvious one was article 9 of the Euratom Treaty which talked about a University Institute. This institute was ultimately established in 1972, but not under the Treaty, but as an intergovernmental project (see Corbett, 2005). Another provision that was linked to higher education is article 57(1) EEC on the mutual recognition of qualifications, which instructs the Council to issue directives for the mutual recognition of diplomas, certificates and other evidence of formal qualifications. Provisions that could act as a basis for a European education policy were, however, not present, so it seemed.

The most important activities in the field of education which were undertaken before 1992 are the European Action Programme in the Field of Education and the Erasmus Programme. The European Action Programme has proven to be a significant step in European education. This was not so much because of its real effects, but more because it marked the beginning of education as an area for policy interest for the European Community and made it a joint responsibility of the Community and the Member States (McMahon, 1995). The 1985 ruling of the European Court of Justice in the Gravier Case (see next section) opened up the way for a regulatory basis of educational actions. Article 128 EEC of the Treaty concerned vocational training but in its judgement the Court ruled that this could also include higher education. Despite this ruling, the decision to establish the Erasmus Programme quotes both articles 128 and article 235 EEC as its legal basis. The Council included article 235 as a basis, with which it became an issue requiring unanimity. Member States began to worry that full use was being made of article 128 and that legal obligations were being imposed on them (European Commission, 2006, p. 103). Substantial amendments were made to article 128 EEC in the Maastricht Treaty and at the same time, a new article was drafted on the quality of education. For the first time, education was included in the primary law in the European Union (article 149 (ex 126)). Research and technology have been part of the Treaties from the beginning. The single most important European action in the field of research, the Framework Programmes (FP), had a clear legal basis in Art 130i EEC. The European role in research appears to be less sensitive than its role in the education sector. This can be explained by the fact that the European dimension in research has been pursued mainly by promoting and (financially) facilitating cooperation. The European role has been distributive rather than regulative and greater cooperation and exchanges of ideas have not yet pushed for more primary legislation in the field of research.

In terms of secondary Law there has been somewhat more regulatory activity, especially in relation to the recognition of qualifications. Various sectoral directives 
were issued in order to implement article 57(1) EEC on recognition. But directives were also issued for matters like the education of children of migrant workers, the right of residence for students and the admission of third country nationals for the purpose of studies or scientific research. The number of directives issued by the Council and the Commission that related to education, training or science has grown gradually and the same is true for Council and Commission Regulations (see figure 3).

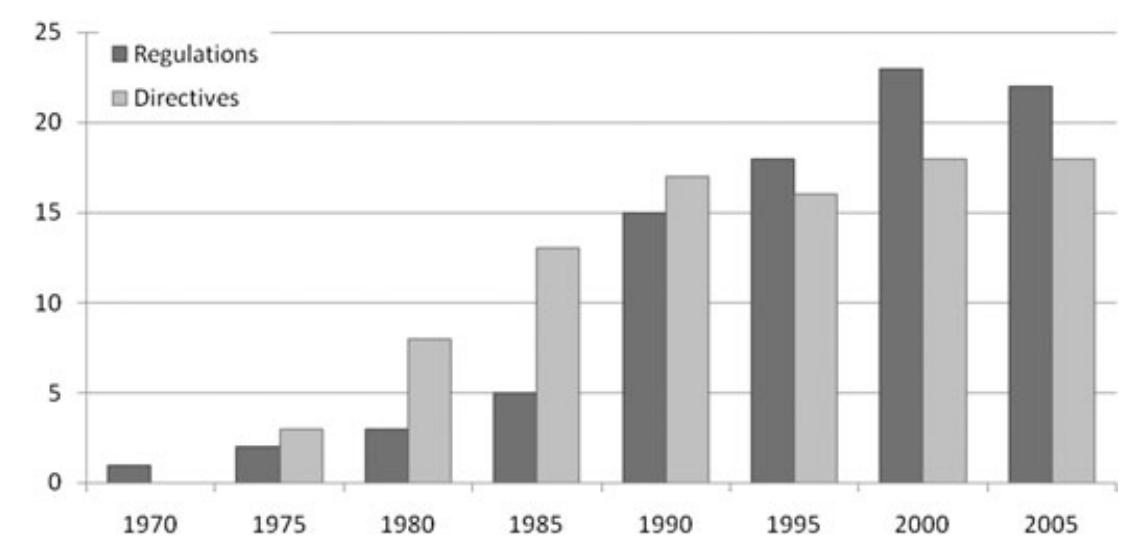

Figure 3. Regulations and Directives in Force in Education, Training and Science, 1970-2005 (Office for Official Publications of the European Communities, 2007) ${ }^{2}$

Member States have thus been very cautious in the development of rules for the fields of higher education and research. They are clearly wary about European interference in their own policies and reforms and a move towards a joint educational policy based on regulative powers of the EU has not gained much momentum. The inclusion of education in the Maastricht Treaty was evidently not meant to increase the Commission's authority in national education and research policies, but to find a legal basis for joint action in transnational matters of education and research and for more cooperation in these sectors. These cooperative activities, however, do not necessarily demand changes in or expansion of the regulative capacity of the EU in the fields of education in research.

\section{The Role of EU Institutions: the Court and the Commission}

The European Court of Justice (ECJ)

Even though education and research have only modestly been affected by rules explicitly aimed at these activities, other rules have had an impact and might gain more profound influences on national policies and systems in the future. Considering the cumulative nature of jurisprudence, an increasing influence of the ECJ in the fields of research and higher education can be observed (see Figure 4). Peaks in activity can be seen in the early 1970 s, the late 1980 s and the first years of the $21^{\text {st }}$ century. 


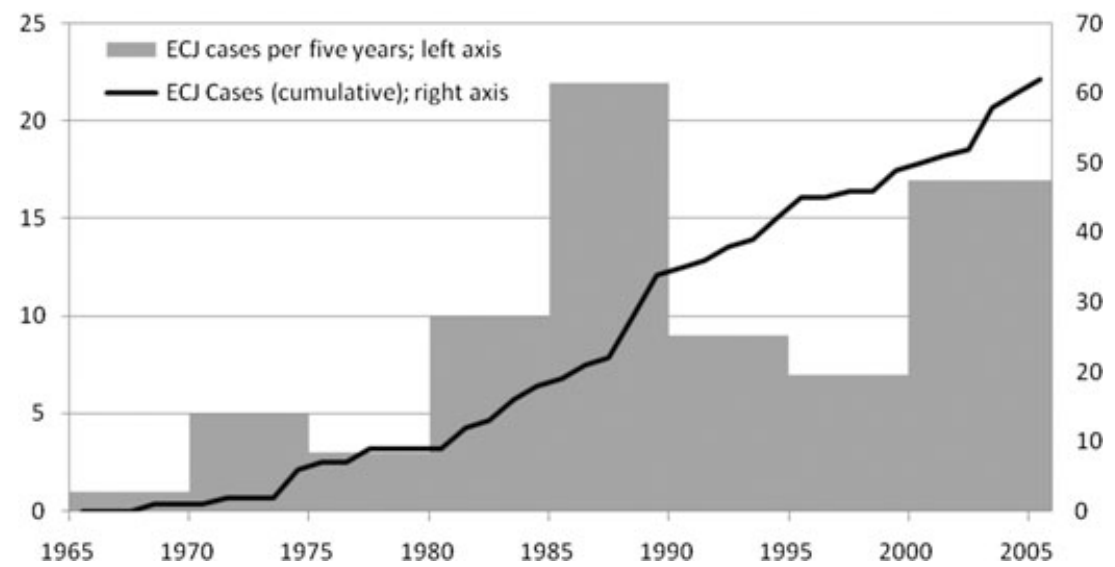

FIGURE 4. ECJ cases in the fields of education and research ${ }^{3}$

A closer look at the contents of the cases reveals that the Court's activity has been modest in the field of research where cases were mainly related to patent issues. In education, the ECJ has extended the role of European law in four main areas: (i) matters related to the right of education of children of migrant workers; (ii) definitional issues related to education and the nature of education; (iii) the provisions related to the recognition of qualifications; and (iv) the applicability of general principles, in particular the non-discrimination provision and the notion of EU citizenship.

The Court's rulings on matters relating to the children of migrant workers mainly referred to Regulation $1612 / 68$, issued to realise article 48 EEC on the free movement of workers. In a range of cases, the Court gave its interpretation on articles 7 and 12 of this regulation. Article 7 secures the equal treatment of migrant workers, including the access to 'social advantages' enjoyed by national workers. The rulings on article 7 of the Regulation ${ }^{4}$ made clear that grants should be made available to workers pursuing vocational courses, as a 'social advantage' under article 7 of Regulation 1612/68. It hereby creates an effect on financial issues such as student support. Article 12 states that children of migrant workers shall be admitted to the host State's educational, apprenticeship and vocational training courses under the same conditions as the nationals of that State. In the judgements relating to article 12 of the Regulation ${ }^{5}$, the Court spelled out that all forms of education are covered by this article and discrimination in access to education is not permitted. Such children must furthermore not be subject to discrimination in relation to maintenance grants.

Most important with respect to definitional issues has been the development of the definition and scope of 'vocational training' in article 128 EEC. A breakthrough was made in the Gravier Case ${ }^{6}$. Building on the Forcheri Case ${ }^{7}$, in Gravier the Court defined vocational training as 'any form of education which prepares for a qualification for a particular profession, trade or employment or which provides the necessary training and skills for such a profession, trade or employment' and added that it applies even if the training programme includes an element of general education. This definition was further refined in subsequent cases on the matter ${ }^{8}$. Although the Commission argued that all university education was vocational, the 
Court implicitly rejected this in its Blaizot judgement (Flynn, 1989). The Court stated that university studies usually fulfilled the criteria of the Gravier definition, but that the only exceptions were courses which were intended to improve general knowledge rather than to prepare for an occupation. Another definitional issue was also brought forward in the Gravier case. The question here was whether education could be seen as a service under the service provisions of the Treaty. The Court ruled that education could not be classified as a service and therefore did not fall within the scope of article $49^{9}$ (ex article 59). In consecutive cases ${ }^{10}$, the distinction between public and private has proved to be crucial. In the Wirth case the Court ruled that courses of higher education provided essentially out of public funds did not constitute 'services' in the meaning of the EC Treaty. In the recent Neri case the Court rules that a course of education that is funded essentially out of private funds, and where the education institute seeks to make a profit, is considered a service of an economic nature. With blurring boundaries between public and private, the demarcation of this distinction might provide an avenue in which the Court might have substantial impact in future cases.

A third area in which the Court has been active is the mutual recognition of qualifications. The most important legal resources in this area are the sectoral directives which were first issued in the late 1970s. Before this, the ECJ based its rulings on general principles of Community law that state that national regulations should not impede the right to free movement and should be non-discriminatory. After the sectoral directives, the Court mainly played a role in those cases where specific legislation did not exist. The recent and current cases before the Court are mainly related to the incomplete transposition of the directives into national law ${ }^{11}$.

Finally, in addressing the Court's role, attention must be given to the general principles of the EU Treaty, in particular the non-discrimination principle and the notion of EU citizenship. In the Gravier case, the ECJ held that the principle of non-discrimination did apply to policies on access to vocational training. It has later on evolved in subsequent cases and the Court has given that article a role which the Member States had never assumed it could have (McMahon, 1995). This provision gives empowerment to individuals who wish to rely on European Law, but at the same time it can severely impact the national competence in certain areas. In a recent case, Commission v Austria ${ }^{12}$, the Court held that Austria had failed to provide equal access to higher education to nationals of other Member States. The Austrian government included a provision in their Universitäts Studiengesetz that students in medicine from other Member States had to meet the criteria that were necessary in their home State to enter the university course. This implied that German students had to meet certain requirements from which Austrian students were exempted. The Court ruled that this provision was a form of indirect discrimination and was therefore incompatible with article 12. The day after the court ruling, 700 German students had already completed initial onlineregistration forms to study medicine at the University of Vienna. The shift in competence becomes all the more clear if one considers that the German and Austrian governments had agreed bilaterally on the issue. Lonbay (2005, p. 76) concludes from these cases that they make clear that, although the primary competence still lies with the Member States, European law can 'nevertheless pack a considerable punch at how states can organise and fund access to higher education'13. Douglan (2005, p. 985) observes that the Maastricht Treaty has succeeded in taming the Community legislature, but at the same time it has 
provided the basis for a new generation of case laws on the equal treatment of foreign students. It has enabled an expansive interpretation of articles 12 (non discrimination) and 18 (European citizenship) for the field of education. In both the Grzelczyk and the Bidar cases ${ }^{14}$ it was made clear that the rights conferred on the basis of EU citizenship were also applicable to students. The Grzelczyk judgement suggests that EU students are entitled to claim maintenance grants when they find themselves in the same situation as nationals of the host Member State. Before the Maastricht Treaty, the Court refused the right to obtain loans and grants while studying in another Member State. The Bidar Case changed this. Here, the Court argues that it is legitimate for a host Member State to grant such assistance to students who have demonstrated a certain degree of integration into the society of that State (although the Court made clear that Member States have a right to protect themselves against 'grant-tourism'). Although the inclusion of the demand for a 'certain degree of integration' will seriously limit the eligibility for grants, the Court again advances the concept of European citizenship in this case.

\section{The European Commission}

While the increasing activity and the expansive role of the ECJ can be assessed on the basis of its judgements, for the Commission the changes in its role are more difficult to evaluate. The most straightforward measure is the financial resources it uses for activities related to higher education and research. This however does not tell the whole story. The ways in which activities change also need to be assessed on the basis of their content and impact, not just in terms of financial resources. If we first look at the financial resources employed in the fields of education and research, we can observe a growth in the last two decades for education as well as research related programmes (figure 5). The Framework Programmes started in 1984 with an annual budget of slightly less than a billion or $2.41 \%$ of the total budget. In two decades this has grown to nearly five times that amount for the years covering the Sixth Framework Programme (2002-2006), now covering 4.39\% of the total budget.

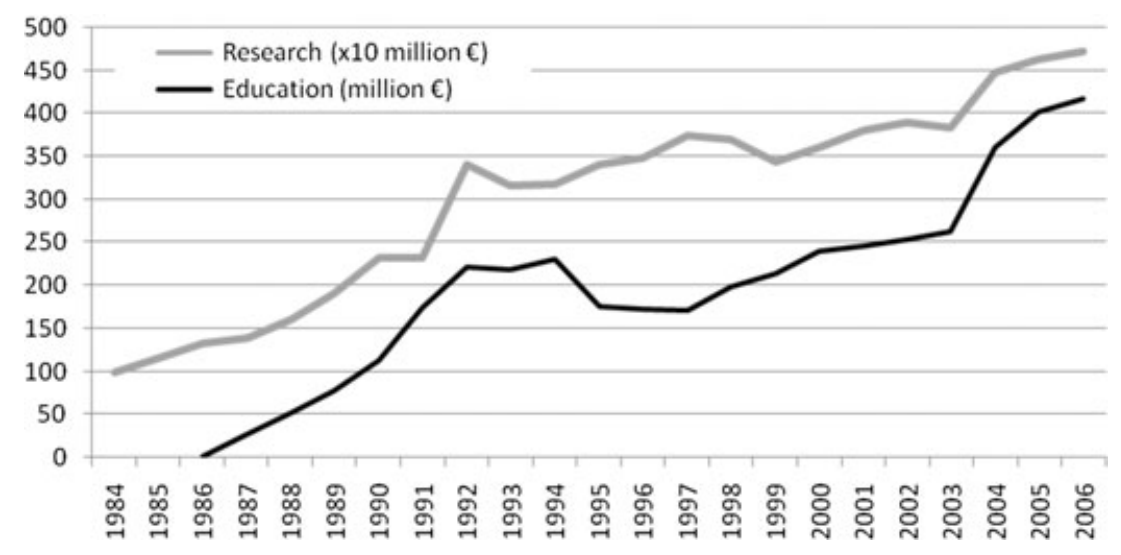

Figure 5. Annual budget for Higher Education and Training ${ }^{15}$ (European Commission 2004, 2006) 
The amount of resources invested in education programmes is considerably less but has nevertheless been growing steadily over the past two decades. The first resources were spread over various programmes and received only modest funding. After 1995, the various activities became part of two major programmes: Socrates and Leonardi da Vinci. Socrates I (1995-1999) had a budget of 920 million Euros and the budget of its follow up, Socrates II (2000-2006), was increased to more than 2 billion Euros. In 2004, two programmes were added to this: the eLearning programme and the Erasmus Mundus Programme. Both have a limited budget, but the funding for the Erasmus Mundus initiative will become more substantial in the future. In terms of financial capacity, one can conclude that the role of the Commission has indeed expanded in the last decades. However, especially considering that the EU had only 10 Member States in 1984 and 25 members in $2005^{16}$, the Commission's capacity in terms of financial resources is only moderate.

The expanding role of the Commission should, however, not be assessed merely on the basis of the growing budget. The Commission has also made education and research a more fundamental concern for the Community. Research was included as a division in the European Commission from the start and was linked to technology and industrial policy. The main seeds for a community policy in research were sown by Altiero Spinelli, who headed the DG for Industry and Research. It took until the early eighties before the most important initiatives, the Framework Programmes, were launched. The FP is now the European Union's main instrument for research funding in the European Union. A new phase for European research started with the Lisbon Agenda in 2000 where Europe first proclaimed its now much cited goal of becoming the most competitive knowledge-based economy in the world. This has provided the Commission with the opportunity of linking research more directly to the economic agenda and therewith claim a more pivotal role for knowledge-related policies. As a result, not only the funding has increased but also the Commission's activity in the field of research, for instance through the establishment of the European Research Council and the European Institute of Technology. The central rationale behind this increased activity was that Europe needed more excellence in order to compete with the US (and in the future with India and China) and that it had to do this on the basis of innovation and knowledge. Since excellence can only be achieved by concentrating the European minds, European level action became opportune, or even necessary ${ }^{17}$.

In education, the Commission has gradually expanded its influence in three overlapping phases. In the first decades of the European Community, by establishing education and research as a domain for European competence and policy (roughly covering the period until the Treaty of Maastricht), later by extending and denationalising the community education and research programmes (1987-2006) and since the turn of the century, by 'Lisbon-ising' education and research. In the 1976 Action Programme, education, for the first time, became a part of the European bureaucracy. Education became a division within the new DG for Research, Science and Education, headed by Ralph Dahrendorf. It took until the year 1999 for Education and Training to be accommodated in a separate Directorate General. In the decades in between, international and European cooperation between universities has moved from a peripheral activity to a central issue with strategic importance. The start of the Erasmus programme in 1987 marked the start for a substantial flow of exchange students within the European Union. But Erasmus was more than the movement of students. After 1995, staff exchange and curriculum 
development also became part of the activities. Erasmus was also a prime networking instrument, bringing academics and administrators from around Europe together to collaborate and communicate. An important managerial change was the Institutional Contract. This encouraged universities to design a coherent internationalisation and Europeanisation strategy. Especially the inclusion of a 'European Policy Statement', in which these strategies had to be formulated, brought European cooperation into the centres of decision-making of European universities. Another interesting step was taken in 1989, when the European Credit Transfer System was adopted in order to facilitate the flow of Erasmus exchange students. In the framework of the Bologna Process, ECTS has developed into an accumulation system to be implemented at the European level before 2010.

In the next major step towards a European Higher Education Area, the Commission was surprisingly absent, although not by choice. The Sorbonne and Bologna Declarations of 1998 and 1999 were purely intergovernmental actions. Parallel to this, however, the Commission had taken a move to link education to the economic future of the EU. The 1997 communication 'Towards a Europe of knowledge' linked the quality of European education to the aspiration of a European knowledge economy. This goal was made more explicit in the Lisbon Strategy, adopted in 2000. This created a Europe with three parallel paths towards a European higher education area: the intergovernmental Bologna Process focusing on system reforms, the European activities in Socrates II focusing on the traditional areas of exchange and networking, and the Lisbon Agenda, emphasising higher education's capacity to contribute to innovation in the European knowledge economy. The traditional European activities in the Socrates framework further institutionalised the exchange and collaboration within Europe, activities that by now have become firmly embedded in the institutional strategies of Europe's higher education institutions. These activities are by and large still additional activities, supplementing - not threatening — domestic agendas of Member States. The new agendas of Bologna and Lisbon have proven to reach deeper at the heart of domestic policies. Bologna has in its first years centred mainly on the systemic reforms needed to implement the bachelor/master system, a purely national task where cooperation did not go further than mutual adjustment on a voluntary basis. The Commission has gradually stepped into this process, focusing mainly on facilitating this process of mutual adjustment. Now this implementation process is well underway in most European countries, the broader lines of action of the Bologna Declaration come to the fore again: the further development and strengthening of the European Higher Education Area and the European Research Area and promoting their attractiveness beyond Europe. Together with an ongoing discourse about the crisis of European universities (partially caused by the emergence of international rankings) and about the sclerotic nature of the European economy, this paved the way for a closer alignment with the competitiveness based Lisbon Agenda. Ultimately this has de facto led to the convergence of the Bologna Process and the Lisbon Agenda into one policy framework (Huisman \& Van der Wende, 2004, pp. 34-35). This convergence can be regarded as a 'Lisbonisation' of Bologna (rather than a 'Bolognafication' of Lisbon) and as a result, the role of the Commission in shaping the reforms throughout Europe has increased. The economic competitiveness ideal of Lisbon has taken the limelight over the educational and cultural ideals of the Bologna process. Keeling (2006, p. 211) observes that 'infected through the Commission's Lisbon Agenda, the main focus (of the 
Bologna Process) becomes the European economy itself, drawing higher education reform more firmly within the EU's policy domain'.

\section{The Emergence of a Transnational Society}

The emergence of a transnational higher education and research society is the third dimension of the EHERA and probably the dimension to which the least attention has been given. This is rather surprising considering the growth in the number of transnational actors in Europe. We can approach the concept of a transnational society in the EHERA in two ways. First of all we can identify the community that has emerged in the core areas of higher education and research, something that I will refer to as the transnational academic community. Secondly, the notion of a transnational society can be seen as the collection of organisations in the political arena that are involved in agenda setting and lobbying. This political community exists of organisations which have an interest in a further integration and institutionalisation of the EHERA.

The European academic community is as old as European academia itself. Links between Europe's centres of learning have existed for long but in the post-war era they have increased rapidly and were transformed from informal ad-hoc networks into a wide range of formalised European organisations with increasing opportunities for communication and exchange. Figure 6 illustrates the increase in transnational academic organisations from 1945 until 2005.

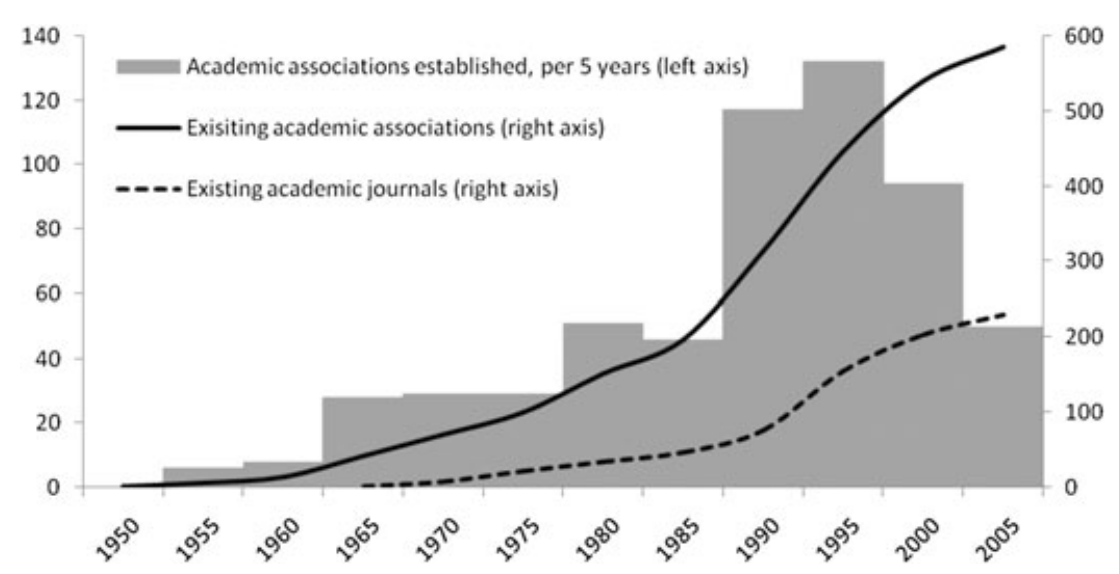

FIgURE 6. European academic associations (1945-2005) ${ }^{18}$ and European academic journals $(1965-2005)^{19}$

The figure plots all discipline-based associations and formalised networks in Europe where academics are the main members and where the exchange of information and collaboration in teaching and research was one of their main missions. In the post-war period, a total of almost 600 of such organisations have been established. The growth of these organisations really took off in the mid1980s when European activity in higher education and research was gradually gaining a foothold. The peak in the founding of new organisations can be observed 
around 1990. Considering that the process of formally founding these organisations can cover several years, it can be concluded that many of the organisations were initiated around the time of the first Erasmus Programme (1987) and the first Framework Programme (1984). In the latter part of the 1990s, the growth of the number of organisations has slowed down and it appears that a saturation point has been reached around the turn of the 21 st century. In about half a century this has led to a situation where nearly all possible disciplines and subdisciplines are represented and organised at the European level. Most of the European academics are somehow linked to these organisations and frequently they are affiliated to multiple transnational organisations. In addition, many disciplinary societies or associations are also organised at the wider international level, further increasing interaction and communication within Europe. In these academic communities, the exchange of information and ideas and collaboration to create new knowledge are the primary goals. Within such organisations, conferences and journals function as the vehicles for communication and information exchange. Not surprisingly, the development of disciplinary journals therefore shows a similar pattern. The strongest growth of European journals can be seen in the early 1990s, whereas it slightly slowed down after the turn of the 21 st century. While in the early 1980 s there were just over 30 real European academic journals, in 2006 this figure exceeded 230. These two indicators show the emergence and institutionalisation of a European academic society. By creating these transnational associations, relations between academics became formalised and the possibility was created for setting up transnational channels for communication, such as conferences and journals.

In addition to an academic community - and partly in response to it - one can also observe the emergence of a community of organisations with more political goals (Figure 7). Three major groups can be distinguished here on the basis of the interests they represent. Interests are organised around certain themes or topics or they are organised around specific groups, most notably, higher education institutions and students. The major growth in the number of such organisations can be seen in the late 1980s and early 1990s. The thematic organi-

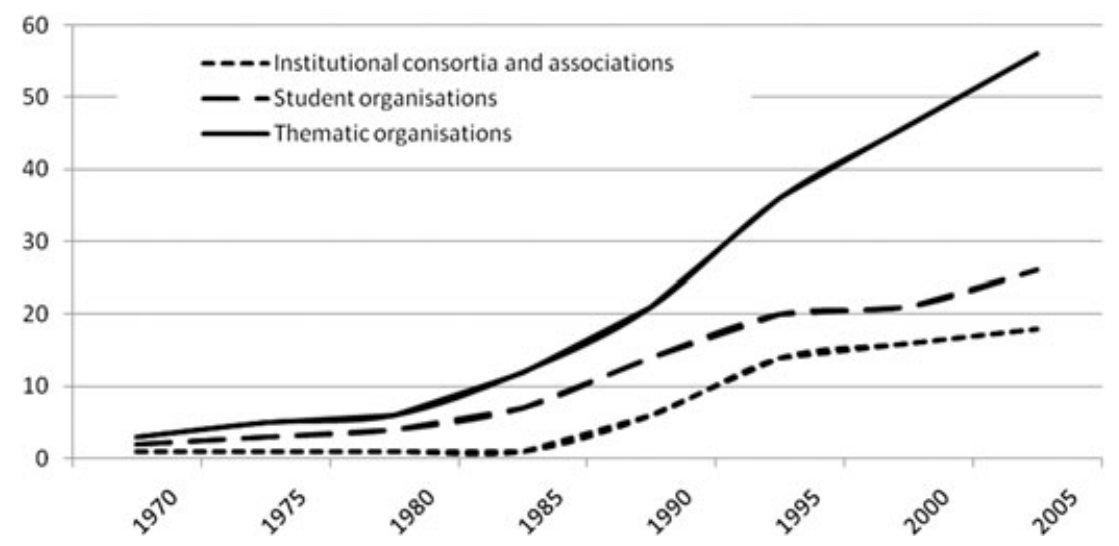

FIGURE 7. Existing interest based organisations in European higher education and research $^{20}$ 
sations are the largest part of this group. These organisations can represent a wide range of interests, for instance relating to religion, to educational themes or to particular activities such as international cooperation, university management or quality assurance. Students are also well represented 'in Brussels'. Most of these student organisations are organised around particular disciplines, some are very broad in scope, presenting the interests of European students in general (ESIB: National Unions of Students in Europe, AEGEE: Association des Etats Généraux des Etudiants de l'Europe). The institutional networks can take on very different forms as well. Some are membership-based consortia created around specific institutional characteristics ('research universities', 'traditional universities', 'innovative universities') while others represents specific types of higher education institutions (universities; other institutions like polytechnics, Fachhochschulen, Hogescholen, etc; distance education universities). These organisations are also involved in collaboration and information exchange, but they have an additional mission in representing specific interests, be it of students, of particular universities or of particular thematic priorities. They have become full partners in the policy making processes, similarly to earlier developments in the national policy context.

These organisations have collectively evolved into a political community at the European level which have become very active in shaping and influencing European policies. Many of these are actively involved in the key European policy processes like the Bologna process (e.g. the European University Association (EUA) and ESIB). They push for European rules to be extended or interpreted in such a way that the interests of their constituents are best served or their thematic priorities are best supported. In a way, the growth of these organisations has resulted in communities that resemble their national equivalents and created a situation where institutions and academics face multiple loyalties, national as well as European. This creates a more complex environment for institutions and individuals to operate in, but at the same time it provides them with new opportunities. They can address different issues to different representative organisations. Where they feel threatened by expansion of European rules and authority, they will call upon their national governments; where they experience obstacles at the European level, they will call upon their European level representatives to act.

\section{The Dynamic Nature of European Integration}

European integration in higher education and research has been a dynamic process that started in the 1970s and really took off in the 1980s. The dynamics in this process can be summarised by two related mechanisms: the logic of institutionalisation and the working of spill-overs. Following Fligstein and Stone Sweet (2001) and Haas (1958), the logic of institutionalisation exists because actors who engage in transnational exchange are the most likely benefactors of coordination and regulation at the European level (unless they are involved in criminal transnational activities); they are the most likely to attack national rules and practices that pose obstacles to transnational activity; hence they lobby governments and supranational institutions to further facilitate mobility and exchange. Transnational exchange will thus favour the development of European institutions and rules which in turn will favour transnational exchange and the institutionalisation of a transnational academic and political community. The result is a self-sustaining dynamic of institutionalisation where transactors demand clearer rules as interde- 
pendence increases. This process has developed in an evolutionary rather than a planned manner and has produced outcomes that key actors could not anticipate or foresee. The logic of institutionalisation at the supranational level thus implies that when supranational rules, supranational organisations and transnational society have emerged, these rules, organisations and transnational actors become active driving forces for further integration. The preceding sections showed that such a logic of institutionalisation is also apparent in the EHERA. The transnational activity of students, really taking off in the 1980s, has pushed the European Court of Justice to interpret the European rules in an expansive manner and the Commission to propose measures to streamline the transfer of students and their credits within the European space. The mobility of professionals has demanded a more transparent system of recognition of degrees and qualifications. The increasing exchange of research results and ideas has stimulated a formalisation of European relations between researchers functioning as a vehicle for further collaboration and exchange. Also, it has stimulated the organisation of interests at the European level of those who are transnationally active, individuals as well as organisations. In a period of a few decades this has led to a European polity in higher education and research that can no longer be ignored. This European polity is not there to support national interests, but the interests of a wide range of transnational groupings, organised around political, scientific, educational or thematic interests.

Another dynamic in regional integration is embodied in the concept of spillover. Functional spill-over has been a major mechanism for integration and the emergence and institutionalisation of the EHERA. Functional spill-over occurs when incomplete integration undermines the effectiveness of existing policies, thereby creating pressures for new European policies. The increasing economic relevance of education and research - in the framework of a European knowledge society - means that several aspects of integration in higher education and research were driven by economic factors. Spill-over from the economy to education happens in a situation in which a given action related to a specific goal creates a situation in which the original goal can be assured only by taking further actions. A common market for professional services for instance, has no real meaning if there is no structure to recognise each other's qualifications. The push for further cooperation in research and the concentration of excellence are explicitly linked to the economic competiveness of the EU. General principles like the principle of non-discrimination have also been linked to sectors like higher education, even though there was no clear functional relation between the principle and the higher education sector. Political spill-over also occurs in the EHERA. Allegiances of universities and of individual academics shift after a new institutional context emerges they shift expectations and political activities and see in the European domain new channels to exert influence. Universities team up with likeminded European universities and open offices in Brussels (or at least travel there frequently). They formulate and publish their official joint opinions. At the same time they remain members of their own national university associations and retain their national organisational linkages. This gives them a choice to activate the right networks and coalitions at the right time. This type of spill-over sets in motion a process of institution building. The European Commission plays a major role in a third type: cultivated spill-over. Cultivated spill-overs occur when problems are deliberately linked together in package deals on the basis of political and ideologi- 
cal projections and political possibilities and not because of technological necessity (Nye, 1970, p. 806). The way that the European Commission has Lisbonised higher education is an example of this spill-over. In cultivating a sense of emergency (and thereby upgrading the European interest), the Commission has also used its discursive power. It did so in particular by stressing the need to catch up with North American higher education and research (and to avoid being overtaken by emerging Asian countries) and by emphasising the need for joint action to reach these goals. In this discourse, the connection between education on the one hand and economic competiveness and sustainable social advancement on the other, is used by the Commission to pursue the Lisbon agenda, and through this, an agenda of European reform in higher education.

\section{Conclusion}

Europe has gained importance in all three dimensions of supranational governance: European rules, the role of European institutions and the emergence and role of a European transnational society. The regulative framework itself has expanded only moderately at the European level, but the ECJ has frequently used an expansive interpretation in education-related cases, especially by relating them to provisions that were not originally intended to affect education or research. The Commission has turned into a significant player. Its financial power has steadily grown, but is still marginal compared to national expenses in the fields. In the last decades the Commission's influence came from its ability to act as a policy entrepreneur and its ability to set and channel the discourse, as illustrated by the Lisbonisation of higher education reforms. In addition, a European academic and political community has emerged in the past decades with the formalisation of links between academics, administrators, students and universities. All three dimensions have driven - and were simultaneously driven by - increasing transnational exchange of students, academics, information and ideas. Establishing causal relations is difficult because of the simultaneity of events and also because the establishment of organisations and the formulation of regulations usually covers a time span of several years. The article has shown that the relationships should be seen as dynamic in nature, where exchange, regulation, institutional strengthening and organisation develop in interaction with each other and jointly push for further supranational governance. This dynamic nature is caused by a loop of institutionalisation and by the expansive logic of sector integration due to various types of spill-over.

The lens through which we have looked at European integration and the institutionalisation of the EHERA might picture the process of Europeanisation as an unstoppable train, relentlessly moving towards a unified Europe. This picture might need some nuance. Although many faces appear to be heading in the same direction at the moment, this is no guarantee for further future institutionalisation of this new supranational layer. Nation States still have the capacity to implement their own educational reforms, even when this is not fully in line with Bologna or Lisbon. We have, however, reached a point in European integration where the costs of pulling out and isolation might become too high and where the presence of transnational actors has become too ubiquitous to neglect. In a phase where the core policy beliefs of many European countries more or less correspond to those of the European Union, such withdrawal tactics are not very likely. Increasing integration 
obviously is easier in a situation where decision makers converge in their ideas about the core policies that need to be pursued. When core policy beliefs diverge, a shift towards the inter-governmentalism end of the continuum is likely.

As long as there is a general consensus on the need for joint European action and on the directions of European level policies, this is likely to lead to a further deepening of the European dimension in higher education and research. With a further growth of intra-European mobility it is also likely that more cases will be presented to the ECJ. Its interpretation of European Law will remain important in demarcating the boundary between national and European authority in higher education. The Commission and other EU-level institutions will most likely try to reinforce their position in the EHERA and the Commission will therefore pursue its discursive strategy of upgrading the common interest. The European transnational society in the EHERA, with both its political and academic communities, shows signs of saturation in terms of its population of organisations, networks and associations. The future of the EHERA will depend very much on how transnational activity will intensify within these networks and how well they manoeuvre between the national interests of their individual members and the common interests of the collectives. This complex net of European organisations and associations might also prove to function as an important buffer for political volatility on the national as well as the European level. Although the formal authority is embedded in the Member States and the EU institutions, the European transnational society is in the position to keep the integration process within bounds or to push it forward, whatever it considers necessary.

\section{NOTES}

1. Data for free movers come from the UNESCO Statistical Yearbook (1978/ 1999) and the Unesco Institute of Statistics Database for host countries Ireland, Denmark, Netherlands, Belgium, Austria, Italy, Spain, France, UK and Germany and region of origin is Europe. Data for 1995-1998 were not available and were entered using simple linear extrapolation.

2. Directives and Regulations in force under classifications 16.30 (Education and Training) and 16.10 (Science) according to EurLex (Office for Official Publications of the European Communities, 2007).

3. All judgements of the ECJ are related to (higher) education and research or had a major impact on it. The list was compiled on the basis of various secondary resources (De Witte, 1989; McMahon, 1995; Tudor, 2005) and searches in the EurLex Database.

4. E.g. Case C-39/86 Lair [1989]; Case C-197/86 Brown [1988]; Case C-235/87 Matteucci [1988].

5. E.g. Case C-9/74 Casagrande [1974]; Case C-68/74 Alaimo [1975]; Case C-389/87 Echternach and Moritz [1989]; Case C-263/86 Humbel [1988]; Case C-308/89 di Leo [1990].

6. Case C-293/83 Gravier [1985].

7. Case C-152/82 Forcheri [1983].

8. In particular the following 3 cases (see McMahon, 1995): Case C-309/85 Barra [1988]; Case C-263/86 Humbel [1988]; Case C-308/89 di Leo [1990]; Case C-24/86 Blaizot [1988]. 
9. Article 49 of the EU Treaty states that 'restrictions on freedom to provide services within the Community shall be prohibited in respect of nationals of Member States who are established in a State of the Community other than that of the person for whom the services are intended'.

10. Especially Case C-263/86 Humbel [1988]; Case C-109/92 Wirth [1993] and Case C-153/02 Neri [2003].

11. E.g. Case C-505/04 Commission v United Kingdom [2005]; Case C-164/05 Commission v France [2006].

12. Case C-147/03; a similar case is Case C-65/03 Commission v Belgium [2004].

13. In this respect, the EU even goes further than the US, where differential fees for in-state and out-of-state students are common, something that would not be allowed under EU law.

14. Case C-184/99 Grzelczyk [2001] and Case C-209/03 Bidar [2004].

15. Only those activities that have a higher education element are listed. Socrates focused on education and non-tertiary education; Leonardo da Vinci on vocational training, including advanced training in higher education.

16. The ten new members of 2004 also received financial resources before their membership through the TEMPUS programmes.

17. Illustrated by the words of Manuel Barosso: 'since the challenge is global, the response has to be European'.

18. The list was compiled from various sources, including the Yearbook of International Organisations (Union of International Associations, 2005), the Directory of European associations in the field of education (European Commission, 1999) and various Internet searches. The list is restricted to organisations with a multinational membership covering a substantial part of Europe. Where associations are continuations of earlier associations or a product of a merger, the date of foundation of the oldest predecessor was taken.

19. (ISSN 2007) All Academic Journals with a pan-European scope. In case of different language editions, the oldest edition is taken. If both online and printed editions exist, the oldest was used to compile this list.

20. Supra note 18 .

\section{REFERENCES}

Corbett, A. (2005) Universities and the Europe of Knowledge. Ideas, Institutions and Policy Entrepreneurship in European Union Higher Education Policy, 1955-2005 (Basingstoke, Palgrave MacMillan).

De Witte, B. (Ed.) (1989) European Community Law of Education (Baden Baden, Nomos Verlag).

Douglan, M. (2005) Fees, grants, loans and dole cheques: who covers the cost of migrant education within the EU, Common Market Law Review, 42, pp. 943-986.

European Commission (1999) Directory of European Associations in the Field of Education (Luxembourg, Office for Official Publications of the European Communities).

European Commission (2004) Report from the Commission on Research and Technological Development Activities of the European Union - 2003 annual report (Brussels, European Commission). 
European Commission (2005) Erasmus Networks now cover nine tenths of Europe's universities, press release IP/05/1313; Brussels, 20 October 2005.

European Commission (2006) The History of European Cooperation in Education and Training (Luxembourg, Office for Official Publications of the European Communities).

Fligstein, N. \& Stone Sweet, A. (2001) Institutionalizing the Treaty of Rome, in: A. Stone Sweet, W. Sandholtz \& N. Fligstein (Eds) The Institutionalization of Europe (Oxford, Oxford University Press) pp. 29-55.

Fligstein, N. \& Stone Sweet, A. (2002) Constructing polities and markets: an institutionalist account of European integration, American fournal of Sociology, 107, pp.1206-1242.

FlynN, J. (1989) Gravier: suite de feuilleton, in: B. DE WitTe (Ed) European Community Law of Education (Baden Baden, Nomos Verlag).

HaAs, E. B. (1958) The Uniting of Europe: Political, Social and Economic Forces 1950-1957 (London, Stevens and Sons).

Huisman, J. \& vAN DER Wende, M. C. (2004) The EU and Bologna: are supra- and international initiatives threatening domestic agendas? European fournal of Education, 39, pp. 349-357.

Isoc (2007) Socrates projects database. http://www.isoc.siu.no.

IsSN (2007) ISSN Portal. http://portal.issn.org.

Keeling, R. (2006) The Bologna Process and the Lisbon Research Agenda: the European Commission's expanding role in higher education discourse, European Fournal of Education, 41, pp. 203-223.

Lindberg, L. (1963) The Political Dynamics of European Economic Integration (Stanford, Stanford University Press).

LonBAy, J. (2005) The European Higher Education Area: two steps closer, European Fournal of Legal Education, 2, pp. 75-76.

McMahon, J. A. (1995) Education and Culture in European Community Law (London, The Athlone Press).

Moravcsik, A. (1993) Preferences and power in the European Community: a liberal intergovernmental approach, Fournal of Common Market Studies, 31, pp. 473-524.

National Science Foundation (2006) Science and Engineering Indicators 2006 (Arlington, NSF).

Nye, J. (1970) Comparing common markets: a revised neo-functionalist model, International Organization, 22, pp. 796-834.

Office for Official Publications of the European Communities (2007) Eurlex Database. http://eur-lex.europa.eu

SAndholtz, W. \& Stone SweEt, A. (Eds) (1998) European Integration and Supranational Governance (Oxford, Oxford University Press).

Stone Sweet, A. \& SANDholtz, W. (1998) Integration, supranational governance, and the institutionalization of the European polity, in: W. SANDHOLTZ \& A. Stone Sweet (Eds) European Integration and Supranational Governance (Oxford, Oxford University Press) pp. 1-26.

Tudor, G. R. J. (2005) Higher Education Law in the European Union. Ph.D. Dissertation, Kent State University.

UNESCO UNESCO Statistical Yearbook (1978/1979-1998 editions) (Paris, UNESCO). 